\title{
Selection of high-yielding varieties and hybrids of pan patty squash, determining their most favorable planting dates
}

\author{
Shavkat Durkhodjaev ${ }^{1, *}$, Sohibjon Islamov $^{1}$, Tulganoy Kenjaeva ${ }^{2}$, and Abdulaziz Tojiboyev ${ }^{2}$ \\ ${ }^{1}$ Tashkent State Agrarian University, Universitetskaya str., 2, 100140, Tashkent, Uzbekistan \\ ${ }^{2}$ Termiz branch of Tashkent State Agrarian University, Yangiobot str., Surkhandarya, Uzbekistan
}

\begin{abstract}
In this article, the results of research on the cultivation of patty pan squash in the climatic conditions of Uzbekistan, Planting for different periods and its growth, development, yield, as well as the impact of weather conditions were presented. Squash is a one-year plant of the family of zucchini, mainly shrub, rarely found in the form of a whip. The results showed that average yield of "White-13" control was 16 tons/ha, and it was 17 tons/ha in "Solnyshko". Furthermore, "NLO White" and "Umberall" had a high yield compared to the other varieties and hybrids, accounted for 15 tons/ha and 15.1 tons/ha, respectively. The highest average temperature during seed germination was found in 16 august, which was $30.3^{\circ} \mathrm{C}$, whereas the lowest average temperature was $18.6^{\circ} \mathrm{C}$ in 1st April. The results showed that 4 days were required to reach $10 \%$ of seed germination in the period April 16 and May 1, however, 10\% of seed germination in July 1 and 16th took 6 days. Furthermore, the least days for $75 \%$ of seed, germination was observed in the period of May 1, accounted for 8 days, and the rest of the period was the same.
\end{abstract}

\section{Introduction}

Continuous population growth justifies the need to increase food crop production and ensure food security. Accordingly, an important task of agricultural production is to intensify the farming culture by obtaining several crops from the same area of land per year [2-4]. The climate of the country is also suitable for this, the warm period lasts 8-9 months: from late February to early March - late November $[1,7,8]$. Squash and patty pan squash is sowed in the world's 1.8 million hectares and 24.7 million tons of gross crops is harvested. Mainly, it is popular in China (7.2 million tons), India (4.9 million tons), Russia (1.3 million tons), Iran (0.9 million tons) and worldwide average yield is 13.7 tons/ha. The highest yields (48.5-65.4 tons/ha) are obtained from the Netherlands, Israel, China and Spain $[3,11]$. Squash is very popular among the population of Uzbekistan. This is due to its high nutritional, dietary and medicinal-prophylactic properties. Pan patty squash fruits contain essential nutrients (carbohydrates, proteins), biologically active substances (vitamins, mineral salts, enzymes, antioxidants, etc.), which makes it a more valuable

\footnotetext{
${ }^{*}$ Corresponding author: shavkat.durkhodjaev@yandex.com
} 
product in a healthy diet. 2-4-day-old young fruits (knots) of pan patty squash are used for vinegar in pumpkin vegetable crops, unripe fruits are used in kitchens and canning industry, ripe fruits are given to livestock as juicy food. Squash plant tufts grow in clumps $[2,4]$. Therefore, they do not require a large feeding area, such as squash and squash hybrids. These crops ripen very quickly, the fruits are technically (farmed) in 50-60 days after germination. As a cultural crop, these stand close to cucumbers.

There are not many varieties of squash and patty pan squash. "Grechesky 110 " variety of squash is widespread. The fruit of this variety is cylindrical in shape, light green in color, light green when technically ripe and when fully ripe. Squash's "White-13" variety is widespread, the fruit is flat plate-like, strongly articulated, the edges are polygonal, the color is light green when cut for consumption purposes, and then completely pale [13]. If the squash is harvested during the fruiting period, it will bear fruit during the summer until the first frost $[5-6,10]$. Therefore, they are sown once in the spring and used from harvest until late autumn. Depending on the growing season and climatic conditions of the year, it is advisable to plant it in April. Pan patty squash and Kabocha squash are planted in scheme of $(120+80) / 2 X 70(60)$ and $(140+80) / 2 X 70(60)$, respectively. Pan patty squash and kabocha squash are strongly damaged by dew, spiders, whiteflies and lice. Against them, sulfur preparations (ISO 0.75-10) level solution, $10-12 \mathrm{~kg}$ of sulfur powder per hectare, $25 \%$ applaud (0.5 1) 10\% danitol (2 1), 5\% sumi-alpha (0.5 1), tilt and topaz-100 (0.3-0.5 1) are effective.

Unripe fruits of pan patty and kabocha squash as cucumber are also used for consumption. Therefore, they are harvested every day to prevent overgrowth. Pumpkin fruits are harvested 7-10 days, squash fruits 3-4 days later. However, for canning squash, it will be late harvested, especially when their diameter is $10-12 \mathrm{~cm}$. When picking ripe fruits, they are cut by pressing the bundle lightly without cutting them. In addition to harvesting, diseased and ripe yellow fruits are also harvested [9, 11-13]. Their presence in the stalk delays plant growth and the formation of new fruit, as well as seriously damages the yield. The average yield of cucumbers in the farms of the country is 100-120 quintals per hectare, pan patty and kabocha squash is 60-120 quintals per hectare, and even 250-300 quintals are harvested in advanced farms [2]. The objectives of the research were 1) to create a collection of varieties and hybrids of pan patty squash, 2) Selection of hybrids for planting pan patty squash at different times, 3) Development of elements of pan patty squash cultivation technology.

\section{Materials and methods}

Scientific research was conducted in 2020 on the land of the laboratory of the Department of "Vegetables" of Tashkent State Agrarian University and the Information Consultation Center (extension center) of the university. The research was carried out using the methodological manual of B. J. Azimov and B. B. Azimov "Methods of conducting experiments in vegetable, melon and potato growing", physical and chemical processes, as well as environmental factors and interrelationships of the region where the product is grown $[9,10]$. The accuracy and reliability of the obtained data were analyzed mathematically and statistically using the generally accepted multivariate method of BA Dospekhov and the computer program SPSS (Statistical Package for Social Science) [5, 6]. In this research, the laboratory conditions were considered to determine the biochemical composition of squash in field experiments and variety testing. Furthermore, the phenological observations, biometric measurements, determination of the average weight of squash fruits and yield per unit area were employed [3, 4]. The 13 squash seeds selected in the study year were sown in the 2 nd decade of April in a pre-prepared experimental field according to the scheme in which each variety and hybrid was installed (Figure 1). 


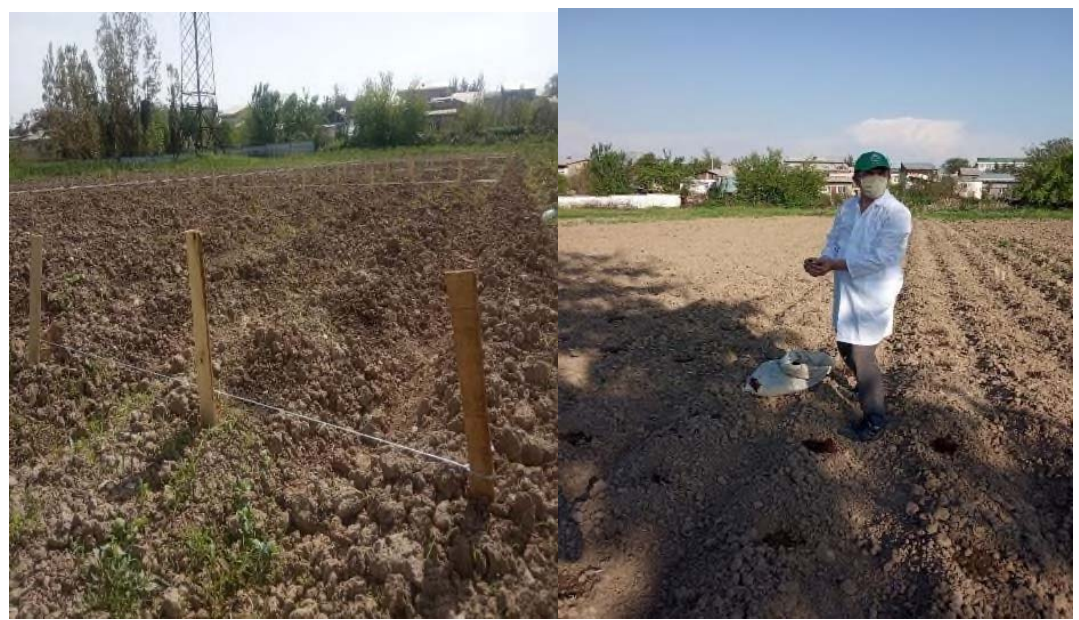

Squash seed sowing processes.

Fig. 1.

\section{Results and discussion}

The results of the experiment showed that the full germination of "White-13" and "Solnyshko" varieties and hybrids of the squash was observed on day 8 , and they took the lead among other varieties and hybrids. In particular, later germination of squash seeds was observed, accounted for 11 days in "Zolotoy medallion" and "Kopeyka", and 10 days in "NLO White" "Cheburashka" as well as "Zarkokil" varieties. The field fertility was $100 \%$, 90\%, 90\% and 85\% in "White-13", "Solneshko" and "Cherepaxa", correspondingly. All other studied varieties and hybrids had a low field fertility of $62-70 \%$ (Table 1 and Figure 2).

Table 1. Field fertility of pan patty squash seeds (2020, days, \%).

\begin{tabular}{|c|c|c|c|c|c|}
\hline \multirow[t]{2}{*}{ \# } & \multirow[t]{2}{*}{ Name of variety and hybrid } & \multirow[t]{2}{*}{$\begin{array}{l}\text { Date of seed } \\
\text { sown }\end{array}$} & \multicolumn{2}{|c|}{$\begin{array}{c}\text { Number of days } \\
\text { from sowing to } \\
\text { full } \\
\text { germination, \% }\end{array}$} & \multirow[t]{2}{*}{$\begin{array}{c}\text { Field } \\
\text { fertility, } \\
\%\end{array}$} \\
\hline & & & 50 & 100 & \\
\hline 1 & White-13 control & 22.04 .2020 & 7 & 8 & 100 \\
\hline 2 & Cheburashka & 22.04 .2020 & 6 & 10 & 75 \\
\hline 3 & Polo F1 & 22.04 .2020 & 7 & 9 & 75 \\
\hline 4 & Cherepaxa & 22.04 .2020 & 6 & 9 & 85 \\
\hline 5 & NLO White & 22.04 .2020 & 7 & 10 & 75 \\
\hline 6 & Solnyshko & 22.04 .2020 & 6 & 8 & 90 \\
\hline 7 & Pyatachok rannespely & 22.04 .2020 & 7 & 9 & 65 \\
\hline 8 & Zolotoy medallion & 22.04 .2020 & 7 & 11 & 62 \\
\hline 9 & Umbrella & 22.04 .2020 & 6 & 10 & 60 \\
\hline 10 & Zontin rannespelyy & 22.04 .2020 & 7 & 10 & 63 \\
\hline 11 & Kopeyka & 22.04 .2020 & 8 & 11 & 65 \\
\hline 12 & Starry rossyp & 22.04 .2020 & 6 & 9 & 68 \\
\hline 13 & Zarkokil & 22.04 .2020 & 7 & 10 & 62 \\
\hline
\end{tabular}




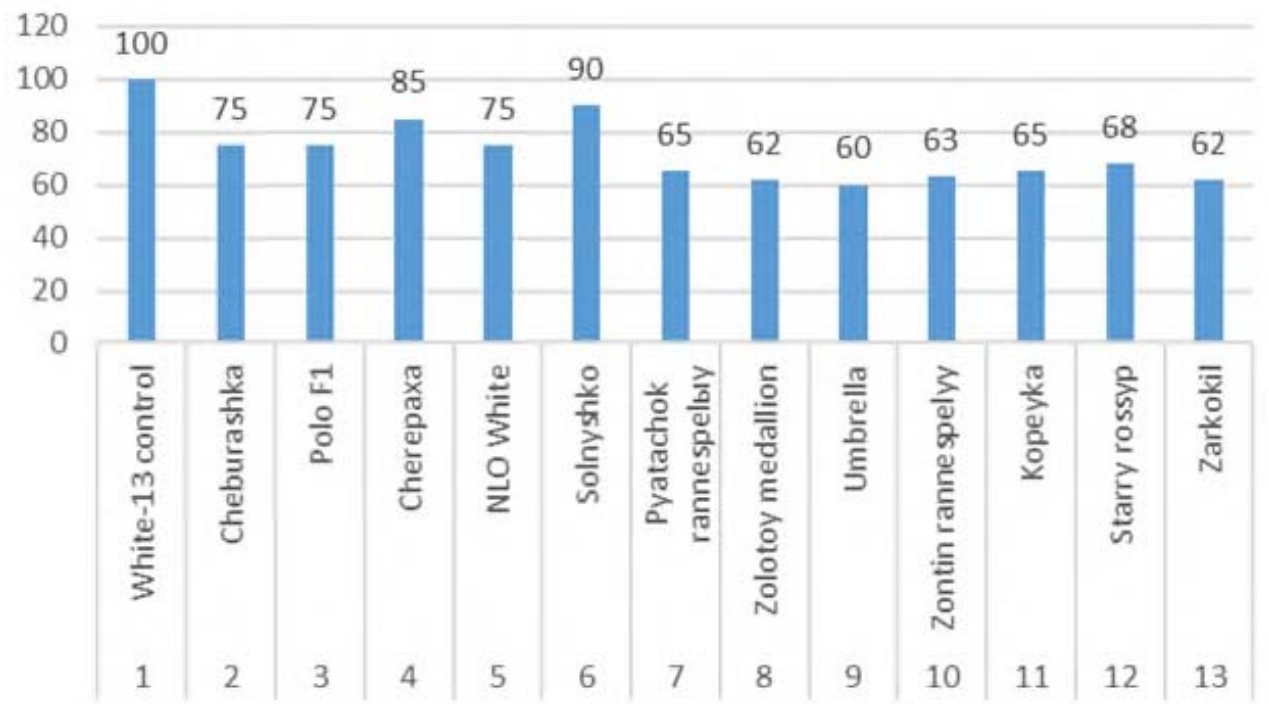

Fig. 2. Field fertility of pan patty squash seeds, $\%$.

The results showed that average yield of "White-13" control was 16 tons/ha, and it was 17 tons/ha in "Solnyshko". Furthermore, "NLO White" and "Umberall" had a high yield compared to the other varieties and hybrids, accounted for 15 tons/ha and 15.1 tons/ha, respectively. The yield of other varieties and hybrids of squash was average of 14.2-14.7 tons/ha. The lowest productivity was found in "Polo F1" and "Cherepakha" in 2020, accounted for 11.5 tons/ha and 13.2 tons/ha, correspondingly (Table 2 and Figure 3).

Table 2. Yield of pan patty squash and hybrids.

\begin{tabular}{|c|l|c|c|c|c|c|c|}
\hline$\#$ & \multicolumn{1}{|c|}{$\begin{array}{c}\text { Name of pan patty squash } \\
\text { and hybrids }\end{array}$} & I & II & III & IV & Total & $\begin{array}{c}\text { Average, } \\
\text { tons/ha }\end{array}$ \\
\hline 1 & White-13 control & 15.0 & 16.0 & 17.0 & 16.0 & 64.0 & 16.0 \\
\hline 2 & Cheburashka & 12.0 & 14.0 & 13.0 & 12.5 & 51.5 & 12.8 \\
\hline 3 & Polo F1 & 10.0 & 11.0 & 12.0 & 13.0 & 46.0 & 11.5 \\
\hline 4 & Cherepaxa & 12.0 & 12.0 & 14.0 & 15.0 & 53.0 & 13.2 \\
\hline 5 & NLO White & 18.0 & 17.0 & 17.0 & 16.0 & 68.0 & 17.0 \\
\hline 6 & Solnyshko & 16.0 & 15.0 & 12.0 & 14.0 & 57.0 & 14.2 \\
\hline 7 & Pyatachok rannespely & 14.0 & 14.5 & 13.5 & 15.6 & 57.6 & 14.4 \\
\hline 8 & Zolotoy medallion & 14.2 & 14.3 & 15.2 & 16.5 & 60.2 & 15.1 \\
\hline 9 & Umbrella & 13.5 & 13.6 & 14.3 & 14.1 & 55.5 & 13.9 \\
\hline 10 & Zontin rannespelyy & 12.9 & 12.5 & 14.0 & 13.5 & 52.9 & 13.2 \\
\hline 11 & Kopeyka & 14.0 & 15.0 & 16.0 & 13.6 & 58.6 & 14.7 \\
\hline 12 & Starry rossyp & 15.5 & 14.9 & 12.7 & 15.6 & 58.7 & 14.7 \\
\hline 13 & Zarkokil & 4.0 & 3.3 & 4.2 & 4.0 & - & - \\
\hline
\end{tabular}




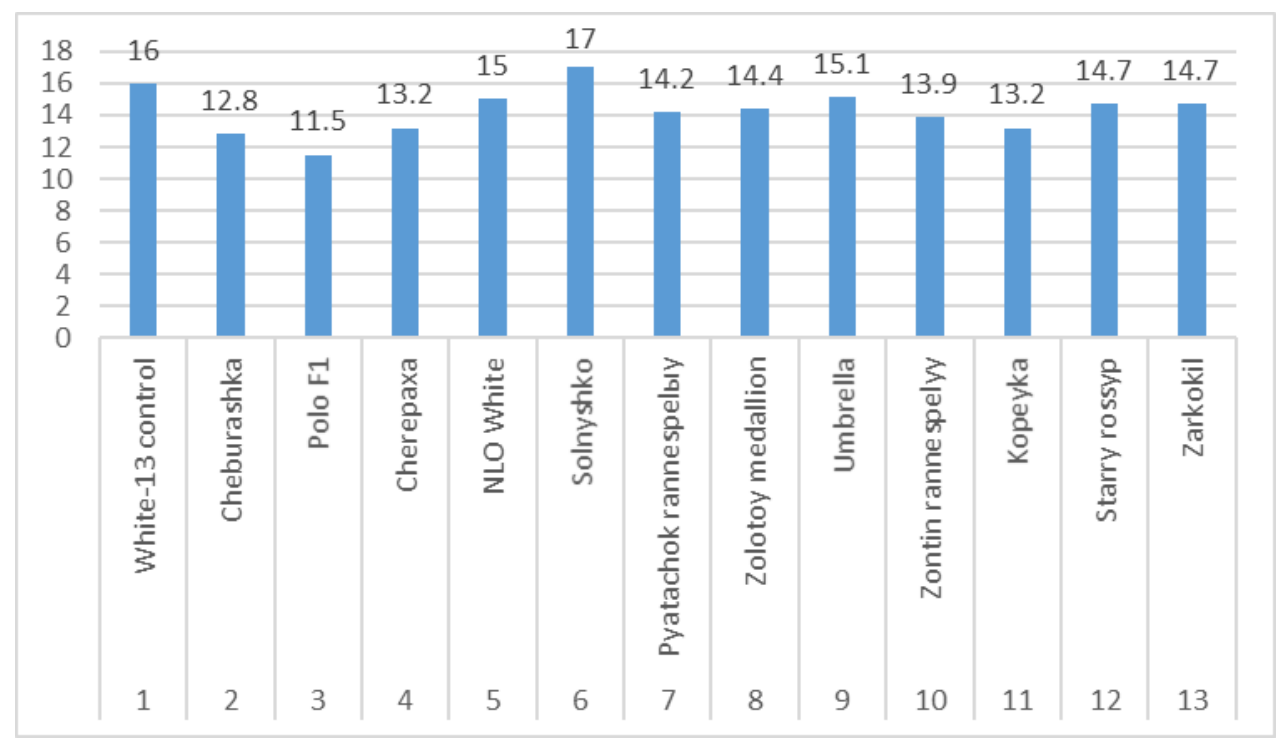

Fig. 3. Average productivity of pan patty squash and hybrids, tons/ha.

In the study, experiments were conducted to determine the most favorable and final possible dates for the cultivation of squash varieties and hybrids as spring and repeat crops. Experiments were carried out with phenological observations, biometric measurements, as in the varietal test. During the experiment, temperature has a significant effect on the sowing and germination of squash seeds.Therefore, effect of temperature on seed germination was also studied in this research.In experience with planting dates, the Solnyshko variety was used.The experiments were conducted in the following periods as: April 1, April 16, May 1, May 16, June 1, June 16, July 1, July 16, August 1 and August 16. The highest average temperature during seed germination was found in 16 august, which was $30.3{ }^{\circ} \mathrm{C}$, whereas the lowest average temperature was $18.6^{\circ} \mathrm{C}$ in 1 st April. The results showed that 4 days were required to reach $10 \%$ of seed germination in the period April 16 and May 1, however, 10\% of seed germination in July 1 and 16 took 6 days. Furthermore, the least days for $75 \%$ of seed germination was observed in the period of May $1^{\text {st }}$, accounted for 8 days, and the rest of the period was the same. The highest indicator in the field germination of seed was found in April 16 and May 16, which was 100\%, while the lowest one was $56 \%$ in June 16 (Table 3 ).

Table 3. Field fertility of patisson seeds, in days and percentages.

\begin{tabular}{|c|c|c|c|c|c|}
\hline \multirow{2}{*}{$\#$} & Sowing dates & \multirow{2}{*}{$\begin{array}{c}\text { Average temperature } \\
\text { during seed germination, }\end{array}$} & \multicolumn{2}{|c|}{$\begin{array}{c}\text { From sowing to } \\
\text { germination, } \\
\text { days }\end{array}$} & $\begin{array}{c}\text { Field germination of } \\
\text { seeds, \% }\end{array}$ \\
\cline { 4 - 6 } & & & $10 \%$ & $75 \%$ & 2020 \\
\hline 1 & 1 April & 18.6 & 5 & 9 & 95 \\
\hline 2 & 16 April & 22.0 & 4 & 9 & 100 \\
\hline 3 & 1 May & 24.3 & 4 & 8 & 90 \\
\hline 4 & 16 May & 26.4 & 5 & 9 & 100 \\
\hline 5 & 1 June & 26.7 & 5 & 9 & 90 \\
\hline 6 & 16 June & 28.7 & 5 & 9 & 56 \\
\hline 7 & 1 July & 29.1 & 6 & 10 & 75 \\
\hline 8 & 16 July & 29.0 & 6 & 10 & 68 \\
\hline 9 & 1 August & 30.0 & 6 & 12 & 72 \\
\hline 10 & 16 August & 30.3 & 7 & 12 & 76 \\
\hline
\end{tabular}


In the experiment year, 2020, there was a continuous increase in the yield of patisson varieties and hybrids by variants. The pertinent results depicted that almost all of the squash varieties and hybrids was started harvesting fruit in about 45-50 days. Basically, full harvest was observed in 60 days. The yield of pan patty squash varieties and hybrids was lasted from 25 to 30 days. The lowest yields in the study year were found in April $1^{\text {st }}$ and 16th, which were 22.3 tons/ha and 22.5 tons/ha, respectively. The highest yield were 39.3 tons/ha on June 1, followed by 43.7 tons/ha on June 16 and 30.4 tons/ha on August 16 . Almost the same yields were observed in the subsequent variants studied in the research, in which the yield was mainly about 25-27 tons/ha (Table 4).

Table 4. Yield and duration of pan patty squash planting periods (days and tons/ha).

\begin{tabular}{|l|l|c|c|c|c|}
\hline \# & Sowing date & $\begin{array}{c}\text { The first } \\
\text { harvest } \\
\text { 45 days }\end{array}$ & $\begin{array}{c}\text { Full harvest } \\
\mathbf{1 5} \text { days }\end{array}$ & $\begin{array}{c}\text { Final } \\
\text { harvest } \\
\text { 25 days }\end{array}$ & Total \\
\hline 1 & 1 April & 7.0 & 7.8 & 7.5 & 22.3 \\
\hline 2 & 16 April & 7.1 & 7.9 & 7.5 & 22.5 \\
\hline 3 & 1 May & 9.1 & 9.5 & 8.8 & 27.4 \\
\hline 4 & 16 May & 6.2 & 9.8 & 9.6 & 25.6 \\
\hline 5 & 1 June & 13.0 & 14.5 & 11.8 & 39.3 \\
\hline 6 & 16 June & 14.8 & 15.9 & 13.0 & 43.7 \\
\hline 7 & 1 July & 11.0 & 12.8 & 9.0 & 32.8 \\
\hline 8 & 16 July & 9.0 & 9.1 & 8.4 & 26.5 \\
\hline 9 & 1 august & 8.3 & 10.0 & 9.0 & 27.3 \\
\hline 10 & 16 august & 10.2 & 12.2 & 8.0 & 30.4 \\
\hline & P, $\%$ & 3.0 & 3.2 & 4.0 & 4.0 \\
\hline & HCP 05 & 3.1 & 0.9 & 1.0 & 2.1 \\
\hline
\end{tabular}

The results of the yield of the pan patty variety and hybrids showed that all squash varieties and hybrids in the other period were surpassed the squash variety in the first period, April 1. The highest harvest was 43.7 tons/ha in June 16, and the lowest one was observed in the period of April 1, accounted for 22.3 tons/ha in 2020. Compared to the first term, the only April 1 had the lowest results, whereas the rest was quite high (Table 5).

Table 5. Effect of pan patty squash planting periods on yield, tons/ha.

\begin{tabular}{|c|c|c|c|}
\hline$\#$ & Sowing dates & $\mathbf{2 0 2 0}$ & $\begin{array}{c}\text { Compared to the first } \\
\text { term, \% }\end{array}$ \\
\hline 1 & 1 April & 22.3 & 100 \\
\hline 2 & 16 April & 22.5 & 100.8 \\
\hline 3 & 1 May & 27.4 & 122.8 \\
\hline 4 & 16 May & 25.6 & 114.7 \\
\hline 5 & 1 June & 39.3 & 176.2 \\
\hline 6 & 16 June & 43.7 & 195.9 \\
\hline 7 & 1 July & 32.8 & 147.1 \\
\hline 8 & 16 July & 26.5 & 118.8 \\
\hline 9 & 1 august & 27.3 & 122.4 \\
\hline 10 & 16 august & 30.4 & 136.3 \\
\hline & P, $\%$ & 1.0 & \\
\hline & HCP 05 & 1.1 & \\
\hline
\end{tabular}




\section{Conclusions}

The results showed that it took an average of 8-11 days for the seeds of squash varieties and hybrids to fully germinate during the year of the experiment. In this case, the full germination of "White-13" and "Solneshko" varieties and hybrids was observed on the 8th day, and they were dominant among other varieties and hybrids. Among the researched squash varieties and hybrids, the some varieties had high field fertility, such as "White-13" was $100 \%$, Solneshko was $90 \%$ and "Cherepaxa" was $85 \%$. All other studied varieties and hybrids had a low field fertility of $62-70 \%$. Furthermore, "NLO White" and "Umberall" had a high yield compared to the other varieties and hybrids, accounted for 15 tons/ha and 15.1 tons/ha, respectively. The yield of other varieties and hybrids of squash was average of 14.2-14.7 tons/ha. The lowest productivity was found in "Polo F1" and "Cherepakha" in 2020, accounted for 11.5 tons/ha and 13.2 tons/ha, correspondingly.

During the experiment, temperature has a significant effect on the sowing and germination of squash seeds. Therefore, effect of temperature on seed germination was also studied in this research. In experience with planting dates, the Solnyshko variety was used.The experiments were conducted in the following periods as: April 1, April 16, May 1, May 16, June 1, June 16, July 1, July 16, August 1 and August 16. The highest average temperature during seed germination was found in 16 august, which was $30.3^{\circ} \mathrm{C}$, whereas the lowest average temperature was $18.6^{\circ} \mathrm{C}$ in 1 st April. The results showed that 4 days were required to reach $10 \%$ of seed germination in the period April $16^{\text {th }}$ and May $1^{\text {st }}$, however, $10 \%$ of seed germination in July $1^{\text {st }}$ and $16^{\text {th }}$ took 6 days.

\section{References}

1. S. Isaev, S. Khasanov, Y. Ashirov, T. Karabaeva, A. Gofirov, In E3S Web of Conferences, 244, 02012 (2021)

2. T. Ostonakulov, V. Zoev, A. Kadirkhijaev, "Navruz" press, 1, 452 (2018)

3. Briefing, V. Zoev, A. Dirie, M. Mukhamedov, National Encyclopedia of Uzbekistan, 478 (Sharq Press, Tashkent, 2002)

4. N. Teshaev, B. Mamadaliyev, A. Ibragimov, S. Khasanov, InterCarto. InterGIS, 26(3), 324-333 (2020)

5. E. Domblides, N. Shmykova, G. Khimich, I. Korotseva, L. Kan, A. Domblides, A. Soldatenko, In VI International Symposium on Cucurbits, $42-48$ (2019)

6. A. Shantasov, S. Sokolov, A. Bocharnikov, V. Maletina, Vegetable crops of Russia, 3, 11 (2015).

7. S. Isaev, S. Khasanov, Y. Ashirov, A. Gofirov, T. Karabaeva, In E3S Web of Conferences, 244, 02047 (2021)

8. R. Kulmatov, A. Taylakov, S. Khasanov, Environmental Science and Pollution Research, 28(10), 12245-12255 (2021)

9. Y. Peng, F. Li, N. Xu, R. Kulmatov, K. Gao, G. Wang, Y. Zhang, Y. Qiao, Y. Li, H. Yang, S. Hao, Q. Li, S. Khasanov, Chinese Journal of Eco-Agriculture, 29(2), 312-324 (2021)

10. T. Wehner, R. Naegele, J. Myers, P. Narinder, K. Crosby, Cucurbits, 32 (2020)

11. A. Jumanov, S. Khasanov, A. Tabayev, G. Goziev, U. Uzbekov, E. Malikov, In IOP Conference Series: Earth and Environmental Science, 614(1), 012150 (2020)

12. I. Aslanov, S. Khasanov, Y. Khudaybergenov, M. Groll, Ch. Opp, F. Li, E. Ramirez Del-Valle, In E3S Web of Conferences, 227, 02005 (2021) 
13. P. Kannaujia, R. Asrey, A. Singh, M. Mahawar, K. Bhatia, Indian Journal of Horticulture, 77, 2 (2020) 